\title{
Family Ownership, Commisioner Independence and Corporate Social Responsibility in Indonesian Corporate
}

\author{
Siti Nuke Nurfatimah \\ Kuningan University \\ sitinuke@uniku.ac.id
}

\begin{abstract}
This study examines the effect of the percentage level of family ownership on CSR information disclosure by family companies in Indonesia after establishing government regulations that require companies to present CSR information. Disclosure of CSR is measured by the content analysis method that refers to the GRI G4 that applies according to the selected research year. In addition, this study also adds a moderating effect, namely independent commissioners who function as independent supervisors of a company. This study took a sample of all family companies in Indonesia except financial companies for 2014 to 2016. Hypothesis testing was done using regression analysis before and after involving moderating effects. The results showed that the level of family ownership had a positive effect on CSR disclosure, but it was not significant. In addition, the role of independent commissioners reduces the influence of family ownership on family CSR disclosures. The existence of independent commissioners increasingly shows that family companies tend to be low in presenting information related to CSR.
\end{abstract}

Keywords: Corporate Social Responsibility, Family Ownership, Commisioners Independent.

JEL Classifications: G32; M14

\section{INTRODUCTION}

The practice of implementing CSR (Corporate Social Responsibility) by companies in Indonesia is still an interesting topic to study. Efforts to improve CSR practices in Indonesia are indicated by the issuance of several regulations including the Bapepam and LK Regulations.

\footnotetext{
${ }^{1}$ The issuance of the regulation simultaneously replaced the Decree of the Chairperson of Bapepam and LK No: KEP134 / BL / 2006 and Decree of the
}

Bapepam and LK issued a regulation Kep-431 / BL / 2012 concerning Submission of Annual Report of Issuers or Public Companies ${ }^{1}$. The regulation contains provisions that annual financial reports must be accompanied by detailed CSR information in its own subtitle. The support of CSR practices, especially on environmental management, was

Chairperson of Bapepam and LK No: KEP-40 / BL / 2007. The duties and functions of the Bapepam and LK moved to OJK (Financial Services Authority) since 31 December 2012 
also shown by the Ministry of Environment by triggering PROPER (Program Rating of Company Performance in Environmental Management). PROPER aims to maximize green sustainability (Abbas, 2016). In addition, the government also stipulates Government Regulation No.47 / 2012 concerning CSR and the environment for limited liability companies and becomes a legal basis for companies that are expected to be able to act as the main actors of CSR and the environment.

Although the Indonesian government has required companies to disclose CSR information in their annual reports. The results of the study by Djajadikerta \& Trireksani (2012) provide evidence that the level of disclosure of CSR made by Indonesian companies is relatively low and the nature of disclosure is mostly descriptive. The results of the study illustrate that in Indonesia, CSR practices are still in the early stages and companies are still not familiar with the importance of CSR. In the East Asia region, Indonesia is a country with a relatively high ranking in terms of concentrated companies and companies under family control (Claessens, Djankov, Lang, \& Kong, 2000). Several studies have proven that the practice of disclosing CSR information is also influenced by corporate ownership forms, especially family ownership (Cabeza-garcía, Sacristán-navarro, \& Gómez-Ansón, 2017; El Ghoul, Guedhami, Wang, \& Kwok, 2016; Elliott \& Jacobson , 1994; Rees \& Rodionova, 2014). Research by Rees \& Rodionova (2014) and El Ghoul,
Guedhami, Wang, \& Kwok (2016) prove that in the Asian region, Indonesian companies under family control tend to have low CSR performance. The results of these studies indicate a negative influence between companies with family ownership and CSR performance. Poor CSR performance in familycontrolled companies has serious agency problems. In line with the research of Cabeza Garcia, Sacristán-Navarro, \& Gómez Ansón (2017) which provides evidence that both family ownership and or family members' power in a company negatively influences the company's commitment to present CSR information. In fact, the presentation of information related to CSR is able to provide a positive signal with respect to the company's reputation (Kim, Park, \& Wier, 2012). But family companies tend to avoid CSR costs and utilization of CSR information by competitors (Elliott \& Jacobson, 1994).

Starting from the results of the study of Cabeza Garcia et al. (2017), this study seeks to complete the CSR disclosure research gap by analyzing the level of ownership of family members in CSR disclosure by family companies in Indonesia. The researcher chose 2014 to 2016 as research year which in that year Indonesia also used the latest CSR practice guidelines, namely GRI G4 and disclosed in sustainability reporting. The researcher also uses the GRI G4 guidelines as a measure of the level of CSR disclosure by family companies. Meanwhile, the level of family ownership in this study was measured using the level 
of the percentage of ordinary share ownership held by family members (Wang, 2006).

Speaking of the low disclosure of CSR by family companies, some literature argues that the need for independent parties involved in the company to reduce agency conflict (Anderson \& Reeb, 2004; Ducassy, 2015; Jensen \& Meckling, 1976). According to the research of Atmaja, Haman, \& Tanewski (2011), independent councils effectively reduce agency conflicts and provide a positive signal regarding transparency of company information to stakeholders. However, the results of the study contradict the research evidence about CSR information disclosed by family companies.

According to CuadradoBallesteros, Rodríguez-Ariza, \& García-Sánchez (2015) that independent parties will lose their independence while in a family company, thereby reducing the positive relationship between family companies and disclosure of CSR information. The results of the research by Sheela, Je-Yen, \& Rajangam (2016) also explain the role of independent boards in companies is less effective in improving CSR performance, especially in family companies. Based on the research evidence, the researcher added a moderating effect, namely the independent party as the party that supervised management performance.

Indonesia uses two tier systems in its governance system. This system separates the role of the supervisory board (board of commissioners) and the executive board / management (board of directors). Because this study uses a sample of family companies in Indonesia, the researcher uses an independent board of commissioners as the party that supervises the board of directors / management. The measurement of an independent board of commissioners is done by dividing the number of independent commissioners by the number of board of commissioners in family companies (Darmadi \& Sodikin, 2013).

This study provides evidence that the level of family ownership has a positive effect on CSR disclosure but is not significant. These results can occur because this study has limitations in the number of samples. Family companies in Indonesia are still not consistent in presenting their CSR disclosures in the sustainability report, thereby reducing the number of research samples that the researchers will use.

In addition, this study also provides evidence that the moderating effect of independent commissioners is to reduce the relationship of family ownership and disclosure of CSR. The level of family ownership negatively affects CSR disclosure. These results can explain the researchers' first findings that independent supervision is not effective in increasing CSR disclosure by family companies. The higher the level of ownership the lower the disclosure of CSR is presented. This evidence shows the 
magnitude of agent conflict in family companies in Indonesia.

\section{LITERATURE REVIEW}

Some theories can explain the relationship between family ownership and CSR disclosure. Agency theory explains that in family companies agency conflicts occur between majority shareholders and minority shareholders (Anderson \& Reeb, 2003). Majority shareholders can control and take over the interests of minority shareholders. In the context of CSR, family companies that have control of the company utilize their rights to limit CSR activities. This view explains that CSR performance is relatively low for family companies (El Ghoul et al., 2016).

Signaling theory explains that managers will convey signals about the state of the company to stakeholders. However, as an impact of information asymmetry, companies use financial statements to signal to investors that they have some favorable information (Sun, Salama, Hussainey, \& Habbash, 2010). Stakeholder theory explains that the existence of a company is not only to fulfill the interests of the owner but also to meet the interests of other stakeholders such as employees, the government and other communities (Sayekti, 2015). In this theory also explained that companies provide information that they believe is right in accordance with what is desired by stakeholders. However, the context of CSR in family companies that limits information related to CSR will have an impact on poor information signals.

\section{CSR and Family Companies}

If a family company produces an efficient organizational structure, then companies with family ownership have limitations to act opportunistically to earnings management. In Indonesia public companies generally have business groups. For companies that belong to the group business, most of the owner's capital is not invested in one company, but is spread across several companies. Opportunistic actions will occur only if the ownership of the scattered company is taken over by shareholders who are one family and the proportion of ownership is categorized as controlling (Siregar \& Utama, 2008).

The family company has the characteristic of concentrating share ownership in the family members of the founding company and the founding family members of the company actively involved in company management, top management or directors (S. Chen, Chen, \& Cheng, 2008). This means that when family members have great strength and hold certain positions in the company, it will influence the decision making process by management. They can control managers and engage in the daily activities of the company (Cuadrado-Ballesteros et al., 2015). Companies under family ownership tend to be less socially responsible than non-family companies, which means that family companies 
provide information on lower CSR practices to avoid costs and avoid the use of information by employees and competitors as well as to maintain corporate reputation and avoid competitive losses (Elliott \& Jacobson, 1994).

Some research results such as Rees \& Rodionova (2014) and El Ghoul, Guedhami, Wang, \& Kwok (2016) that use samples of family companies in Asia prove that in the Indonesian region, companies with family control tend to produce low CSR performance. The higher the family ownership, the lower the CSR performance of the company. The low level of CSR performance can be due to agency conflicts in family companies that are quite serious. In line with the results of Cabeza Garcia's research, Sacristán-Navarro, \& Gómez-Ansón (2017) that both family ownership and or family members' power in a company negatively influences the company's commitment to present CSR information.

Based on these scientific findings, the researchers speculate that in Indonesia the company under family control will result in a relatively low CSR performance.

$\mathrm{H} 1$ : The percentage of family ownership has a negative effect on CSR disclosure.

CSR, Independent Commissioner and Family Companies

Family companies with the presentation of information related to low CSR activities need to find a solution. Restrictions on CSR information will harm minorities.
According to Anderson \& Reeb (2004) and Ducassy (2015) to overcome agency conflicts between minorities and majority parties, an independent party is needed. Ducassy (2015) further explained that this independent party has an important role to improve CSR information, in which independent parties are able to act fairly on all stakeholders.

In line with the results of the study by Cuadrado-Ballesteros et al. (2015) which proves that the higher the proportion of independent parties in the company the higher the level of CSR disclosure. However, in the family company the independence of independent parties disappeared thereby reducing its positive relationship with disclosure of CSR information. This is because independent parties may be friends or there is a binding relationship with the owner of the family company.

In line with the study of Abdullah \& Mohamad (2011) which proves that the role of independent parties becomes ineffective when in a family company. Dominant family members in the company have a negative impact on the independent council's decision on CSR. Therefore, independent parties are unable to increase the disclosure of corporate CSR information.

The results of Sheela, Je-Yen, \& Rajangam (2016) also explain the low independence of the board in family companies, so there is a limited role of independent parties because of the dominant effects of family members in the company. 
Based on the results of previous research and the background of family companies in Indonesia, the researchers suspect that independent parties / independent commissioners clarify agency conflicts between shareholders by weakening the influence of family ownership on CSR disclosures.

$\mathrm{H} 2$ : The effect of the percentage of family ownership on CSR disclosures was moderated by independent commissioners.

\section{METHOD, DATA AND ANALYSIS}

The sample selection in this study was carried out by using a purposive sampling technique with the criteria that the selected company was a company listing on the Stock Exchange in 2014-2016, the company was not a financial company, the company issued 2014-2016 sustainability reporting, the company was a family company. based on the determination of the criteria obtained six companies that passed. Secondary data is used in this study by downloading the sustainability reporting and annual report through each company's website.

CSR measurement as the dependent variable in this study uses content analysis techniques by referring to the GRI G4 indicator (91 indicators) which includes economic, social and environmental aspects. The researcher gives a score of " 1 " to the company that presents information related to the CSR indicator and " 0 " if it does not present the information. Next, after giving a score the researcher adds and averages the score. The average CSR value of each company is used to find out how many companies disclose their CSR activities to the public.

The family company in this study is an independent variable. The family companies referred to in this study are companies whose founders and founding families own shares in the company and / or founding family members become part of the board of commissioners or top management (Anderson \& Reeb, 2003). Referring to Wang (2006), the measurement of family ownership in this study uses the percentage of ordinary share ownership by the founding family members. The percentage of ownership is able to describe the voting power that is owned by family members in decision making.

The researcher also uses moderating variables namely independent commissioners. Independent commissioners are calculated by dividing the number of independent commissioners by the number of all commissioners per company (Atmaja et al., 2011). In addition to the variables mentioned earlier, the researcher also added control variables namely size, ROA and year dummy.

The analytical tool used to test the hypothesis in this study is multiple regression analysis. The first step is to examine the effect of the percentage of family ownership on CSR disclosure. While the second stage examines the moderating effect of independent 
commissioners on the influence of the percentage of family ownership on CSR disclosure. The research model of this study is

\section{Model A}

$$
\begin{aligned}
\mathrm{CSR}_{i t}= & B_{0}+B_{1} \mathrm{Fam}_{\mathrm{it}}+\mathrm{B}_{2} \mathrm{SIZE}_{i \mathrm{t}}+ \\
& \mathrm{B}_{3} \mathrm{ROA}_{\mathrm{it}}+\varepsilon \ldots \ldots \ldots(\mathrm{EQ} 1)
\end{aligned}
$$

\section{Model B}

$$
\begin{aligned}
\mathrm{CSR}_{\mathrm{it}}= & \mathrm{B}_{0}+\mathrm{B}_{1} \mathrm{Fam}_{\mathrm{it}}+\mathrm{B}_{2} \mathrm{Cl}_{\mathrm{it}}+ \\
& \mathrm{B}_{3} \mathrm{Fam}^{*} \mathrm{Cl}_{\mathrm{it}}+\mathrm{B}_{4} \mathrm{SIZE}_{\mathrm{it}}+ \\
& \mathrm{B}_{5} \mathrm{ROA}_{\mathrm{it}}+\mathrm{B}_{6} \mathrm{DY} \mathrm{O}_{\mathrm{it}}+ \\
& \mathrm{B}_{7} \mathrm{DY} \mathrm{DZ}_{\mathrm{it}}+\varepsilon \ldots \ldots \ldots .(\mathrm{EQ2})
\end{aligned}
$$

Explanation:

$\mathrm{CSR}_{\mathrm{it}}$

$\begin{aligned} \text { Fami }_{\mathrm{t}}= & \text { Family companies are } \\ & \text { measured by the } \\ & \text { percentage of ordinary } \\ & \text { share ownership by } \\ & \text { family members for } \\ & \text { company } i \text { in year } t . \\ \mathrm{Cl}_{\text {it }} \quad & \text { Independent } \\ & \text { Commissioners are } \\ & \text { measured based on the } \\ & \text { percentage of } \\ & \text { independent } \\ & \text { commissioners compared } \\ & \text { to the total number of } \\ & \text { commissioners } \\ & \text { company } i \text { in year } t . \\ = & \text { Company size } \\ & \text { measured using natural } \\ \text { SIZE }_{\text {it }} & \text { logarithms of total assets } \\ & \text { in company } i \text { in year } t . \\ = & \text { Return on Asset is } \\ & \text { measured by dividing } \\ & \text { profit after tax divided }\end{aligned}$

by total assets for company $i$ in year $t$.

DY_01 $1_{\text {it }}=$ "1" for 2014, "0" other than that year

DY_02 $2_{\text {it }}=$ "1" for 2015, "0" other than that year

$\varepsilon=$ error

\section{RESULT AND DISCUSSION}

The first hypothesis in this study states that the level of family ownership has a negative influence on CSR disclosure Based on the RSquare value in Table 1, Model $A$ in this study is able to explain the variable disclosure of CSR (dependent) by $46.6 \%$. Hypothesis testing is presented in Table 2 Model A. The test results show that the level of family ownership has a positive but not significant relationship to disclosure of CSR information. Therefore, it can be stated that the first hypothesis in this study is not supported. Table 2 Hypothesis Test Model A (In model A, only the ROA variable is significant at alpha $5 \%$, which means that the level of ROA (financial performance) of a family company has a significant positive effect on CSR disclosure. For other independent variables there is no significant effect.

The research findings for Model $A$ are in line with the results of research by Dyer \& Whetten (2006) and Berrone, Cruz, Gomez-Mejia, \& Larraza-Kintana (2010) that there is a positive influence between companies under family control and CSR performance. This is because family companies prioritize their reputation in front of shareholders. Family companies have the view that 
the impact of this reputation not only affects the company's performance but also the name of the company. According to Kim et al. (2012) managers can use CSR information to improve a company's reputation and limit its opportunistic behavior. Family owners and managers also position the company as a part of themselves so that when the company's reputation is not good, they will feel hurt.
The findings in Model A show different results from the researchers' expectations. This might happen because, in this study the number of companies is very limited. Therefore, it cannot clearly show the effect of the variance in the level of ownership on CSR disclosure in Indonesia. This is a limitation in this study and opens up opportunities for developing this research in the future.

Table 1. Model A (Before Interaction)

\begin{tabular}{llrrr}
\hline Model A & $\mathrm{R}$ & $\mathrm{R}$ Square & $\begin{array}{c}\text { Adjusted R } \\
\text { Square }\end{array}$ & $\begin{array}{c}\text { Std. Error of the } \\
\text { Estimate }\end{array}$ \\
\hline 1 & $.681^{\mathrm{a}}$ & .464 & .240 & .117488 \\
\hline
\end{tabular}

Table 2. Hypothesis Test Model A (Before Interaction)

\begin{tabular}{|c|c|c|c|c|c|c|}
\hline \multirow{2}{*}{\multicolumn{2}{|c|}{ Model A }} & \multicolumn{2}{|c|}{ Unstandardized Coefficients } & \multirow{2}{*}{$\begin{array}{c}\text { Standardized } \\
\text { Coefficients } \\
\text { Beta }\end{array}$} & \multirow[t]{2}{*}{ senta } & \multirow[t]{2}{*}{ Sig. } \\
\hline & & $\mathrm{B}$ & Std. Error & & & \\
\hline \multirow{6}{*}{1} & (Constant) & .467 & .293 & & 1.593 & .137 \\
\hline & FamOwn & .000 & .001 & .063 & .280 & .785 \\
\hline & Size & -.007 & .013 & -.111 & -.525 & .609 \\
\hline & $\mathrm{ROA}$ & 1.737 & .624 & .640 & 2.783 & .017 \\
\hline & DY_01 & -.035 & .068 & -.125 & -.514 & .617 \\
\hline & DY 02 & .030 & .069 & .106 & .431 & .674 \\
\hline
\end{tabular}

The second hypothesis in this study states that the influence of the level of family ownership on CSR disclosure is moderated by independent commissioners. Based on the R-Square value in Table 3, Model B in this study is able to explain the variable disclosure of CSR (dependent) by 63.5\%. The results of testing the second hypothesis are presented in Table 4 using Model B. The test results showed significant interaction of independent commissioners $\left(\mathrm{FAM}^{*} \mathrm{Cl}\right)$ at alpha $10 \%$. This finding proves that independent commissioners are able to act as moderators, but are weakening relationships. The level of family ownership negatively affects CSR disclosure and is significant at alpha $10 \%$. Whereas, in testing the previous hypothesis in Model A (Table 2) the influence of the level of family ownership and disclosure of CSR is positive. Based on these findings, it can be stated that the second hypothesis in this study is supported. 
Consistent with the findings in Model A, the ROA variable in Model B also shows a significant positive effect on alpha $5 \%$ on CSR disclosure variables. These findings indicate that the financial performance of family companies has a significant positive effect on disclosure of CSR information. While other variables do not show significant influence or other changes.

Table 3. Model B (After Interaction)

\begin{tabular}{llrrrr}
\hline Model B & $\mathrm{R}$ & R Square & \multicolumn{1}{c}{$\begin{array}{c}\text { Adjusted R } \\
\text { Square }\end{array}$} & $\begin{array}{c}\text { Std. Error of the } \\
\text { Estimate }\end{array}$ \\
\hline 1 & $.797^{\mathrm{a}}$ & .635 & .380 & .106157 \\
\hline
\end{tabular}

Table 4. Model B Hypothesis Test (After Interaction)

\begin{tabular}{|c|c|c|c|c|c|c|}
\hline & \multirow{2}{*}{ Model B } & \multicolumn{2}{|c|}{ Unstandardized Coefficients } & \multirow{2}{*}{$\begin{array}{c}\text { Standardized } \\
\text { Coefficients } \\
\text { Beta }\end{array}$} & \multirow[t]{2}{*}{$\mathrm{t}$} & \multirow{2}{*}{ Sig. } \\
\hline & & $\mathrm{B}$ & Std. Error & & & \\
\hline \multirow{8}{*}{1} & (Constant) & .432 & .297 & & 1.452 & .177 \\
\hline & FamOwn & -.009 & .005 & -1.772 & -1.881 & .089 \\
\hline & Comm_Ind & .132 & .725 & .068 & .183 & .859 \\
\hline & Size & -.008 & .013 & -.125 & -.606 & .558 \\
\hline & $\mathrm{ROA}$ & 2.531 & .951 & .932 & 2.662 & .024 \\
\hline & $\mathrm{FAM}^{*} \mathrm{Cl}$ & .035 & .017 & 1.817 & 2.033 & .069 \\
\hline & DY_01 & -.035 & .061 & -.125 & -.567 & .583 \\
\hline & DY_02 & .042 & .063 & .152 & .670 & .518 \\
\hline
\end{tabular}

The findings in Model $B$ are in line with the results of the study of Cuadrado-Ballesteros et al. (2015), Abdullah \& Mohamad (2011) and Sheela, Je-Yen, \& Rajangam (2016) which prove that independent parties (independent commissioners) are unable to increase CSR information disclosure by family companies. The family relations felt in family companies make it difficult for independent commissioners to carry out their duties as supervisors of company management. The dominance of family members in company management can influence the decisions of independent commissioners.
Another finding in Model B that is more interesting is that after the interaction of independent commissioners occurs, there is a change in the direction of influence between the level of family ownership and disclosure of CSR. The results of the interaction show the level of family ownership has a significant negative effect on disclosure of CSR information. This finding makes it clear that there is an agency conflict that occurs between the majority (family interests) and minority parties in family companies in Indonesia. This finding is in line with the research of Rees \& Rodionova (2014) and El Ghoul, Guedhami, Wang, \& Kwok 
(2016) and Cabeza Garcia, SacristánNavarro, \& Gómez-Ansón (2017) which prove that firms under family ownership tend to be lower present information related to CSR. The effect of family members involved in management makes the company's commitment in providing CSR information decreasing, so there is clearly a serious agency conflict in family companies in Indonesia.

\section{CONCLUSION}

This study examines the effect of the level of family ownership on disclosure of CSR information. The first finding of this study is that there is a positive relationship between the level of family ownership and disclosure of CSR. However, these findings indicate statistically insignificant values. This research is hampered by the limited number of research samples because of the inconsistency of companies in Indonesia in presenting a Sustainability Reporting report to measure CSR disclosure.

The second finding in this study is the existence of independent commissioners reducing the influence of the level of family ownership on CSR disclosure. The strength of family members involved in the company is able to influence the decisions of independent commissioners so that the role of independent commissioners as supervisors in company management is not effective. This moderating effect is able to show the magnitude of agency conflict in family companies in Indonesia. This is shown in the third finding of this study, namely the level of family ownership has a negative effect on CSR disclosure after including the interaction of independent commissioners. This finding supports researchers' initial assumption that family companies in Indonesia tend to present lower CSR information. Family companies in Indonesia are more careful in presenting CSR information to safeguard the company's reputation and they are reluctant to issue greater CSR costs for the presentation of CSR information.

\section{IMPLICATION/LIMITATION AND SUGGESTION}

This study is a development of previous research, namely Cabeza Garcia et al. (2017) by using the percentage of family ownership as a measure of family companies in influencing disclosure of CSR information. In the first hypothesis the researchers were unable to show that the level of family ownership had a negative influence on CSR disclosure. Researchers suspect because the low sample research factors make the results of this study less than optimal. Companies in Indonesia are still not consistent in presenting Sustainability Reporting, thus hampering this research. Therefore, this finding opens opportunities for further research by increasing the size of the research sample. The addition of this sample of research can be done by increasing the number of years of research and conducting research between countries. 
This study also provides an illustration that agency conflicts can arise in family companies in Indonesia for the presentation of CSR information after involving independent commissioners as moderators. As we know that family companies attach great importance to corporate reputation, making it possible for family companies to limit CSR information that is detrimental to the company's reputation. In addition, the magnitude of the influence of family relationships in the company makes decisions related to the company will always prioritize the interests of family members. This finding also opens up opportunities for further research involving other types of ownership in the presentation of CSR information

\section{REFERENCE}

Abbas, A. (2016). Corporate Social Responsibility ( CSR ) Lingkungan dan Implementasinya di Indonesia: Perspektif Kritis di bawah Ajaran Teori Legitimasi. The Indonesian Social Justice Network.

Abdullah, S., \& Mohamad, N. (2011). Board Independence, Ownership And CSR Of Malaysian Large Firms. Corporate Ownership \& Control, 8(2), 467-483. Retrieved from http: / / www.wbiconpro.com/4 45-ShamsuL.pdf

Anderson, R. C., \& Reeb, D. M. (2003). American Finance Association Founding-Family Ownership and Firm
Performance: Evidence from the $S$ \& $P 500$ Published by: Wiley for the American Finance Association Stable URL: http://www.jstor.org/stable/3 094581 Your use of the JSTOR archive indicates yo. The Journal of Finance, 58(3), 13011328.

Anderson, R. C., \& Reeb, D. M. (2004). Board composition: balancing family influence in S\&P 500 firms. Administrative Science Quarterly, (49(2)), 209237.

Atmaja, L. S., Haman, J., \& Tanewski, G. (2011). The role of board independence in mitigating agency problem II in Australian family firms. British Accounting Review, 43(3), 230246.

http://doi.org/10.1016/j.bar.2 011.06 .006

Berrone, P., Cruz, C., Gomez-Mejia, L. R., \& Larraza-Kintana, M. (2010). Socioemotional Wealth and Corporate Responses to Institutional Pressures: Do Family-Controlled Firms Pollute Less? Administrative Science Quarterly, 55(1), 82-113. http://doi.org/10.2189/asqu.2 010.55.1.82

Cabeza-garcía, L., Sacristánnavarro, M., \& Gómez-ansón, S. (2017). Family involvement and corporate social responsibility disclosure. Journal of Family Business Strategy, 8(2), 209122.

http://doi.org/10.1016/j.jfbs. 2017.04.002

Chen, S., Chen, X., \& Cheng, Q. (2008). Do Family Firms Provide More or Less Voluntary Disclosure? Journal of Accounting Research, 46(3), 499-536. 
Chen, Y. C., Hung, M., \& Wang, Y. (2018). The effect of mandatory CSR disclosure on firm profitability and social externalities: Evidence from China. Journal of Accounting and Economics, 65(1), 169-190. http://doi.org/10.1016/j.jacce co.2017.11.009

Claessens, S., Djankov, S., Lang, L. H. P., \& Kong, H. (2000). The Separation of Ownership and Control in East Asian Corporations. Journal of Financial Economics (Vol. 58).

Cuadrado-Ballesteros, B., Rodríguez-Ariza, L., \& GarcíaSánchez, I. M. (2015). The role of independent directors at family firms in relation to corporate social responsibility disclosures. International Business Review, 24(5), 890901.

http://doi.org/10.1016/j.ibusr ev.2015.04.002

Darmadi, S., \& Sodikin, A. (2013). Information Disclosure by Family-Controlled Firm. Asia Review of Accounting, 21(3), 223-240.

Djajadikerta, H. G., \& Trireksani, T. (2012). Corporate social and environmental disclosure by Indonesian listed companies on their corporate web sites. Journal of Applied Accounting Research, 13(1), 21-36. http: / /doi.org/10.1108/096754 21211231899

Ducassy, I. (2015). Corporate Social Performance, Ownrship Structure, and Corporate Governance in France. Research in International Business and Finance.

http://doi.org/10.1016/j.ribaf .2015.02.002
Dyer, W. G., \& Whetten, D. a. (2006). Family Firm and Social resposibility: Preliminary Evidence from the S\&P 500. Entrepreneurship: Theory and Practice, (801), 785-803.

El Ghoul, S., Guedhami, O., Wang, H., \& Kwok, C. C. Y. (2016). Family control and corporate social responsibility. Journal of Banking and Finance, 73, 131146.

http://doi.org/10.1016/j.jban kfin.2016.08.008

Elliott, R. K., \& Jacobson, P. D. (1994). Costs and Benefits of Business information. Accounting Horizons, 8(4), 8080. Retrieved from http: / / proxy.lib.siu.edu/login? url=http: / / search.ebscohost.co $\mathrm{m} /$ login.aspx?direct=true $\mathrm{ddb}=\mathrm{b}$ th\&AN=9503010837\&site =ehost - live\&scope=site

Jensen, M. C., \& Meckling, W. H. (1976). Theory of the firm: Managerial behavior, agency costs and ownership structure. Journal of Financial Economics, $3(4)$, 305-360. http: / / doi.org/10.1016/0304405X(76)90026-X

Kim, Y., Park, M. S., \& Wier, B. (2012). Is Earnings Quality Associated with Corporate Social Responsibility? The Accounting Review, 87(3), 761796. http: / /doi.org/10.2308/accr10209

Marra, A., Mazzola, P., \& Prencipe, A. (2011). Board monitoring and earnings management pre- and post-IFRS. International Journal of Accounting, 46(2), 205-230.

http://doi.org/10.1016/j.intac c. 2011.04.007 
Martínez-Ferrero, J., RodríguezAriza, L., \& García-Sánchez, I. M. (2016). Corporate social responsibility as an entrenchment strategy, with a focus on the implications of family ownership. Journal of Cleaner Production, 135, 760770.

http://doi.org/10.1016/j.jclep ro.2016.06.133

Mcguinness, P. B., Vieito, P., \& Wang, M. (2017). CSR Performance in China: The Role of Board Gender and Foreign Ownership. Journal of Corporate Finance, 42, 72-99. http://doi.org/10.1016/j.jcorp fin.2016.11.001

Rees, W., \& Rodionova, T. (2014). The Influence of Family Ownership on Corporate Social Responsibility : An International Analysis of Publicly Listed Companies. Corporate Governance: And International Review, 23(3), 184-202. http://doi.org/10.1111/corg.1 2086

Rusmanto, T., \& Williams, C. (2015). Compliance Evaluation on CSR Activities Disclosure in Indonesian Publicly Listed Companies. Procedia - Social and Behavioral Sciences, 172, 150-156.

http://doi.org/10.1016/j.sbspr o.2015.01.348

Samara, G., Jamali, D., Sierra, V., \& Parada, M. J. (2018). Who are the best performers? The environmental social performance of family firms. Journal of Family Business Strategy, 9(1), 33-43. http://doi.org/10.1016/j.jfbs. 2017.11.004

Sayekti, Y. (2015). Strategic Corporate Social Responsibility
(CSR), Company Financial Performance, and Earning Response Coefficient: Empirical Evidence On Indonesian Listed Companies. Procedia - Social and Behavioral Sciences, 211, 411-420.

http://doi.org/10.1016/j.sbspr o.2015.11.054

Sheela, S. D., Je-Yen, T., \& Rajangam, N. (2016). Board composition and corporate social responsibility in an emerging market. Corporate Governance (Bingley), 16(1), 35-53.

http: / / doi.org/10.1108/CG-052015-0059

Siregar, S. V., \& Utama, S. (2008). Type of earnings management and the effect of ownership structure, firm size, and corporate-governance

practices: Evidence from Indonesia. International Journal of Accounting, 43(1), 1 27.

http://doi.org/10.1016/j.intac c.2008.01.001

Srinidhi, B. N., He, S., \& Firth, M. (2014). The effect of governance on specialist auditor choice and audit fees in U.S. family firms. Accounting Review, 89(6), 2297-2329. http://doi.org/10.2308/accr50840

Sun, N., Salama, A., Hussainey, K., \& Habbash, M. (2010). Corporate environmental disclosure, corporate governance and earnings management. Managerial Auditing Journal, 25(7), 679700.

http://doi.org/10.1108/026869 01011061351

Wang, D. (2006). Founding family ownership and earnings quality. 


\section{Journal of Accounting Research, 44(3), 619-656. http: //doi.org/10.1111/j.1475 $-679 X .2006 .00213 . x$}

Waworuntu, S. R., Wantah, M. D., \& Rusmanto, T. (2014). CSR and Financial Performance Analysis: Evidence from Top ASEAN
Listed Companies. Procedia Social and Behavioral Sciences, 164(August), 493-500. http: //doi.org/10.1016/j.sbspr o.2014.11.107 